\title{
Columns with Different Cross Section using ANSYS Work Bench
}

\author{
Prabhu. L, Aravindan. V, Amal Joseph, Edwin Joseph, Abhijith V R
}

\begin{abstract}
In this paper we are going to analyze the strength of material and deflection due to applying load on the column. The column of different materials will be cross sectioned and will present the difference of strength of materials by ANSYS workbench. The strength of material will depend upon the young's modulus and moment of inertia of the metal plate. We use different size of metal plates such as I-section, circular bar, rectangular bar and square bar for a specific material to know the strength of material when a load applied on the cross sections. In this paper we taken a condition that one side of column is fixed and another side is free when load is applying on the column.
\end{abstract}

Keywords : ANSYS Workbench, Column, Crippling Load, Buckling.

\section{INTRODUCTION}

The strength of material and deflection due to applying load on the column will be analyzed using the following numerical solution,

$$
\mathrm{PCr}=\frac{\pi^{2} \varepsilon I}{L_{c}^{2}}
$$

Where,

Pcr $=$ Crippling load $(\mathrm{N})$

$\varepsilon=$ Young's Modulus of Used Material $(\mathrm{N} / \mathrm{m} 2) \mathrm{I}=$ Moment of Inertia (m4)

Lc $=$ Characteristics Length $(\mathrm{m})$

The strength of material will depend upon the young's modulus and moment of inertia of the metal plate[1]. We use different size of metal plates such as I-section, circular bar, rectangular bar and square bar for a specific material to know the strength of material when a load applied on the cross sectioned columns[2]. The above formula is used for the

Revised Manuscript Received on December 16, 2019

* Correspondence Author

L.Prabhu*, Assoc. Professor Department of Mechanical Engineering Aarupadai Veedu Institute of Technology Vinayaka Mission Research Foundation, India.

Aravindan Varadan, Assistant Professor Mechanical Department, Aarupadai Veedu Institute of Technology, Vinayaka Mission's Research Foundation, Deemed To Be University, India.

Amal Joseph, UG Student,Department of Mechanical Engineering, Aarupadai Veedu Institute of Technology, Vinayaka Mission Research Foundation, India.

Edwin Joseph, UG Student, Department of Mechanical Engineering, Aarupadai Veedu Institute of Technology, Vinayaka Mission Research Foundation, India.

Abhijith V R, UG Student, Department of Mechanical Engineering, Aarupadai Veedu Institute of Technology, Vinayaka Mission Research Foundation,India. condition when the load applied openly on the columns, but in this analysis one side of column is fixed and another side is free when load is applied on the column[3]. Then the above formula changed as:-

$$
\mathrm{P} \mathrm{Cr}=\frac{0.25 \pi^{2} \varepsilon I}{L_{c}{ }^{2}}
$$

Where,

$\mathrm{Pcr}=$ Crippling load $(\mathrm{N})$

$\mathrm{E}=$ Young's Modulus of Used Material $(\mathrm{N} / \mathrm{m} 2) \mathrm{I}=$ Moment of Inertia (m4)

Lc $=$ Characteristics Length $(\mathrm{m})$

We use only concrete material in the form of different type of columns[4]. The young's modulus of concrete is $3 \times 1010$ $\mathrm{N} / \mathrm{m} 2$ and moment of inertia varies according to different size of the material and we take 3 meter characteristics length of the columns[5].

\section{A. Columns}

Column is a vertical member which is having the effective length more than three times of its least lateral dimension carrying compressive loads.

Based on shape columns can be classified into Square, Rectangular, and Circular, L-Type, T-Type, V-Type, Hexagon and Arch type as shown in Fig. 1 to 8.

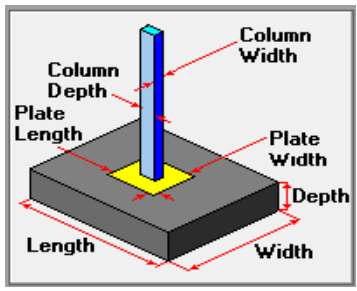

Fig. 1.square column.

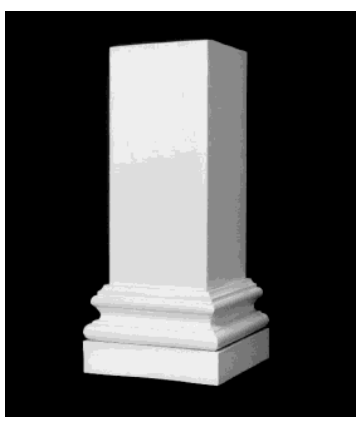

Fig. 2. Rectangular column. 


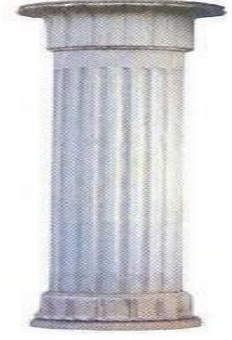

a)

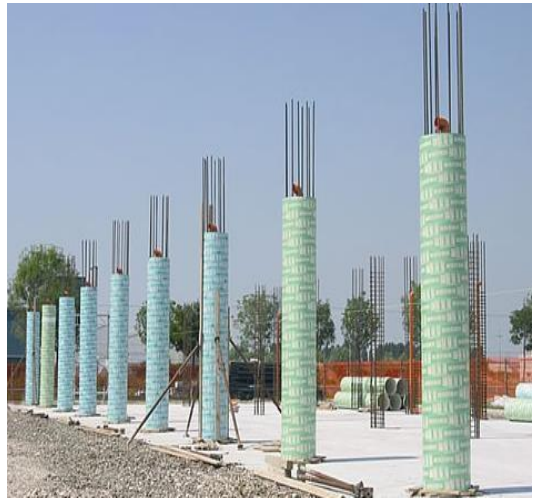

b)

Fig. 3.a) \& b)Circular Column.

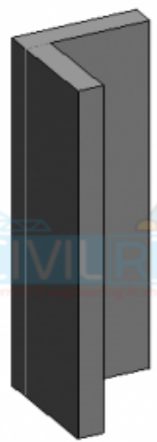

L-type column.

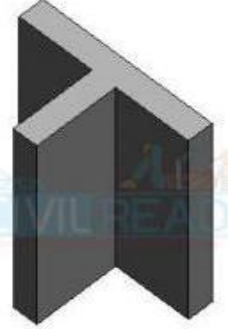

Fig. 4.T-type column.

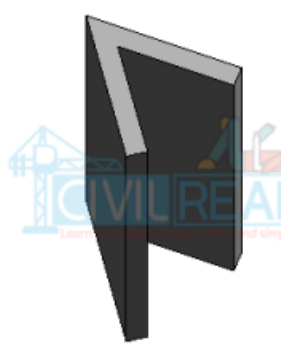

Fig. 5.V-type column.

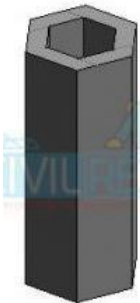

Fig. 6.Hexagonal column.

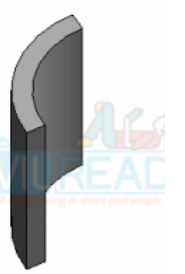

Fig. 7.Arch type column.

Based on type of reinforcement, columns can be classified to Tied Column, Spiral Column and Composite Column as shown in Fig. 9.

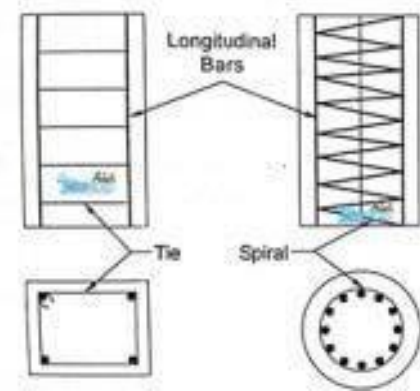

a)

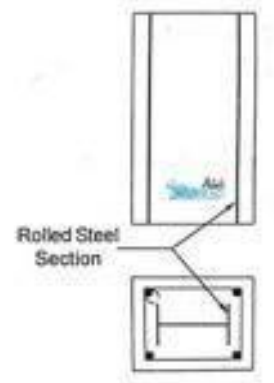

c)
Fig. 8.(a) Tied Column (b) Spiral Column (c) composite Column .

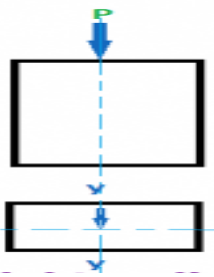

a)

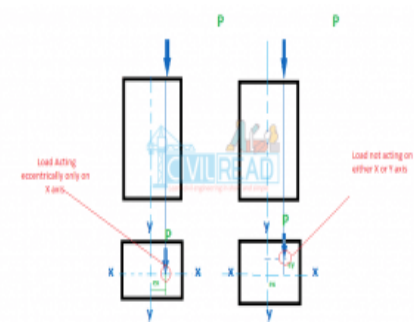

b)
Fig. 9. (a)Axially loaded column , (b) Eccentrically loaded column .

Based on the type of loading columns can be classified to Axially loaded column and Eccentrically loaded column as shown in Fig. 10. Similarly the linked column is shown in the figure 11 and neck column shown in the figure 12 . 


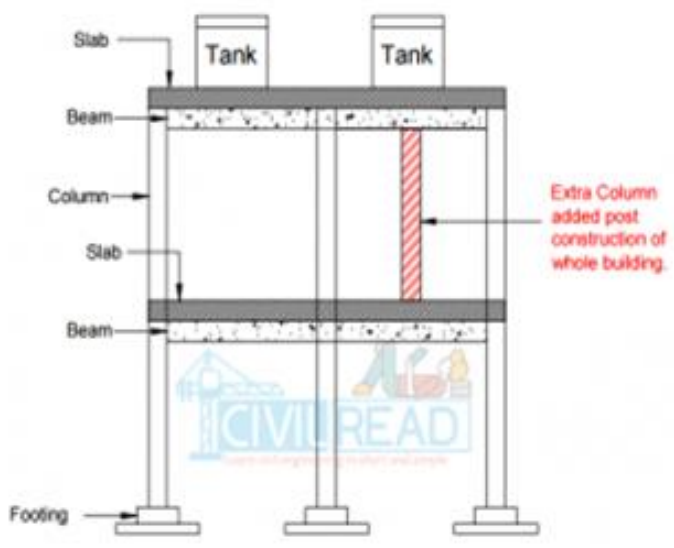

Fig. 10. Stub Column/ Floating column / Linked Column.

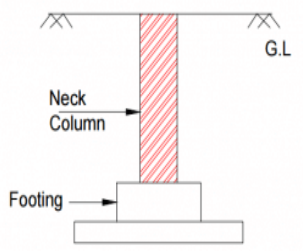

Fig. 11. Neck column.

\section{MATERIALS AND METHODS}

Numerical analysis were carried out for the I Section, Rectangular and circular beam shown in the figure 13-15.

\section{A. I-Section}

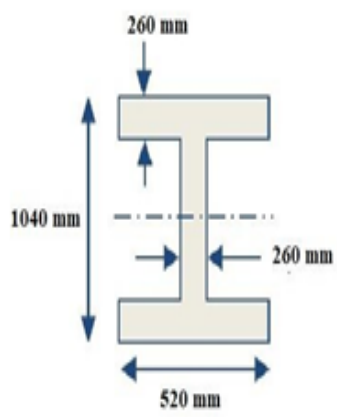

Fig. 12. 13 I-Section.

\section{Calculation:-}

$$
\begin{aligned}
& \rho=2300 \mathrm{~kg} / \mathrm{m}^{3} \\
& E=3 \times 10^{10} \mathrm{~N} / \mathrm{m}^{2} \\
& I_{x x}=45697601536 \mathrm{~mm}^{4} \\
& I_{y y}=6854640128 \mathrm{~mm}^{4}
\end{aligned}
$$

We take one side fixed and one side free condition, then $\mathrm{n}=0.25 \mathrm{~N}$

$$
P_{C_{r}}=n \frac{\pi^{2} E I}{L_{c}^{2}}
$$

$$
\begin{aligned}
& \rho=2300 \mathrm{~kg} / \mathrm{m}^{3} \\
& E=3 \times 10^{10} \mathrm{~N} / \mathrm{m}^{2} \\
& I_{x x}=55924051948 \mathrm{~mm}^{4} \\
& I_{y y}=3495253248 \mathrm{~mm}^{4}
\end{aligned}
$$

One side fixed and one side free condition we take 
$P_{C_{r}}=\frac{0.25 \pi^{2} \times 3 \times 10^{10} \times 3495253248 \times 10^{-12}}{3^{2}}$

$P_{C_{X}}=\frac{7.4022 \times 10^{10} \times 3495253248 \times 10^{-12}}{9}$

$P_{C_{r}}=\frac{7.4022 \times 10^{10} \times 3495253248 \times 10^{-12}}{9}$

$P_{c_{r}}=28.747 \times 10^{6}$

\section{RESULT AND DISCUSSION}

\section{A. I-Section}

Figure 16 shows the ANSYS model for I-section

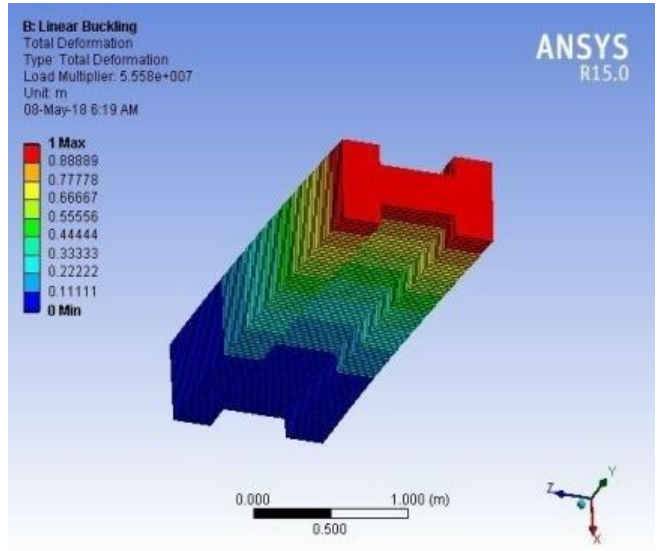

Fig. 15. I-Section.

Simulation of I-Section

Crippling load of I-Section is $=55.58 \times 106 \mathrm{~N}$.

\section{B. Circular Beam}

Figure 16 shows the ANSYS model for circular beam.

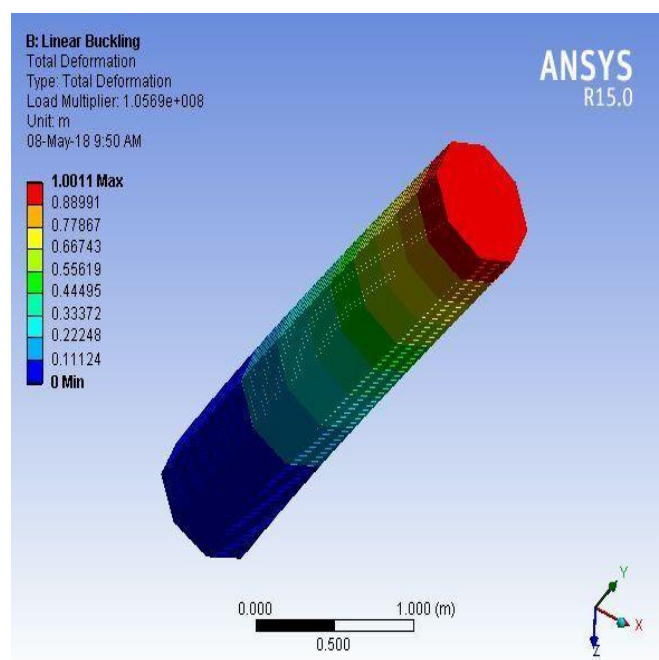

Fig. 16. Simulation of Circular Beam.
Crippling load of Circular Beam is $=105.69 \times 106 \mathrm{~N}$.

\section{Rectangular Beam}

Figure 18 shows the ANSYS model for Rectangular beam.

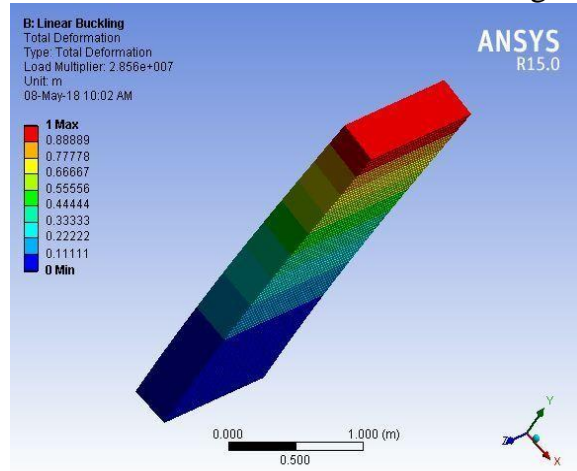

Fig. 17. Simulation of Rectangular Beam.

Crippling load of Rectangular Beam is $=28.56 \times 106 \mathrm{~N}$.

Table- I: Comparison and Discussion

\begin{tabular}{|l|l|l|l|}
\hline Types of Beams & $\begin{array}{c}\text { Numerical } \\
\text { Analysis }\end{array}$ & $\begin{array}{c}\text { Simulation } \\
\text { Analysis }\end{array}$ & $\%$ Error \\
\hline I-Section Beam & $P_{C_{r}}=56.337 \times 10^{6} \mathrm{~N}$ & $P_{C_{r}=55.58 \times 106}$ & 1.343 \\
\hline Circular Beam & $P_{C_{r}}=108.49 \times 10^{6} \mathrm{~N}$ & $\begin{array}{l}P_{C_{r}} \\
=105.69 \times 106 \mathrm{~N}\end{array}$ & 2.580 \\
\hline Rectangular Beam & $P_{C_{r}}=28.747 \times 10^{6} \mathrm{~N}$ & $P_{C_{r}=28.56 \times 106}$ & 0.650 \\
& & $\mathrm{~N}$ & \\
\hline
\end{tabular}

Consider a circular and a rectangular column of side D, D*B. The cross sectional area of circular column will be higher when compared to rectangular columns which is shown in the figure 19. Also, the moment of interia of the circular columns will be much higher than that of the rectangular/square columns. Thereby, less dangerous towards buckling.Even in terms of reinforcement,

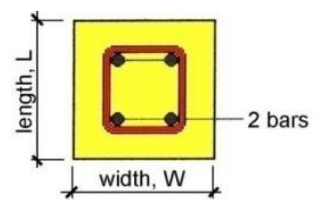

a)

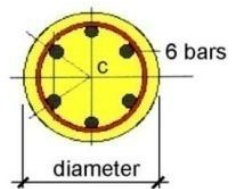

b)
Fig. 18. Cross sectional area of a)Rctangular b)Circular Min. no. of bars in rectangular column is 4 . Whereas, min. no. of bars in a circular column is 6 .

\section{CONCLUSION}

- Due to their Slenderness ratios, circular cross section columns are better.

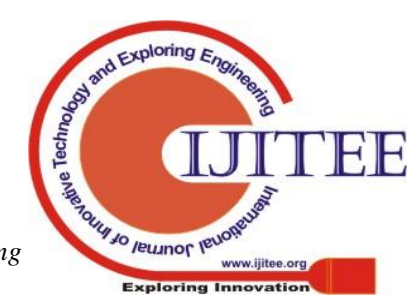


- Rectangular cross-section is prominent for buckling where circular cross section resists it to maximum extent.

- Circular columns do not have weak corners and stress concentration is nil.

- Shear reinforcement having spiral forms gives better result than any other form of ties.

- As Circular cross section does not have any folds, hence load can be distributed evenly across.

- Rectangular cross section is more prominent to bending compare to circular cross section.

\section{REFERENCES}

1. S. Y. Sastry ,Y. Krishna ,A. Koduganti ," Flexural buckling analysis of thin walled lipped channel cross section beams with variable geometry", International Journal of Innovative Research in Science, Engineering and Technology, Jun 2014,Vol.3,No.6,pp.13484-94.

2. V. N. Lê, and H. Champliaud," Safety factor of beam-column structures based on finite element linear buckling analysis", Espace publications,Aug.2013.

3. American Bureau of Shipping, "Guide for buckling and ultimate strength assessment for offshore structures", ABS, April.2004.

4. T. Subramani ,A. Sugathan," Finite element analysis of thin walled-shell structures by ANSYS and LS-DYNA", International Journal of Modern Engineering Research. Vol.2,No.4,Aug.2012,pp.1576-87.

5. R. K. Bansal, "A textbook of strength of materials", Laxmi Publications; 2010,pp.1-1106.

\section{AUTHORS PROFILE}

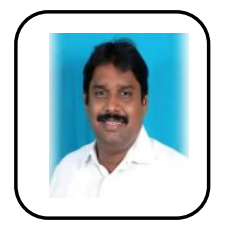

L.Prabhu, Assoc. Professor, Department of Mechanical Engineering Aarupadai Veedu Institute of Technology Vinayaka Mission Research Foundation .

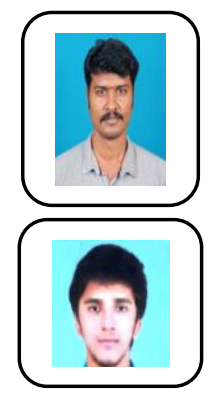

Aravindan Varadan, Assistant Professor, Mechanical Department, Aarupadai Veedu Institute of Technology, Vinayaka Mission's Research Foundation, Deemed To Be University

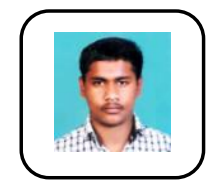

Edwin Joseph, UG Student, Department of Mechanical Engineering, Aarupadai Veedu Institute of Technology, Vinayaka Mission Research Foundation

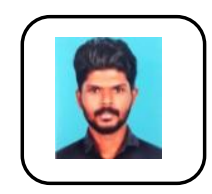

Abhijith V R, UG Student, Department of Mechanical Engineering, Aarupadai Veedu Institute of Technology, Vinayaka Mission Research Foundation 